\title{
Hypertonic Stress Promotes the Upregulation and Phosphorylation of Zonula Occludens 1
}

\author{
Cornelia Then ${ }^{a}$ Tobias Bergler ${ }^{a}$ Roland Jeblick ${ }^{a}$ Bettina Jung ${ }^{a}$ \\ Bernhard Banas $^{\text {a }}$ Bernhard K. Krämer ${ }^{\text {b }}$

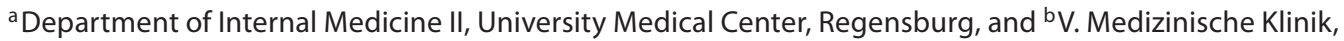 \\ Universitätsklinikum Mannheim, Universität Heidelberg, Germany
}

\section{Key Words}

Cell shrinkage $\cdot$ Cytoskeleton $\cdot$ Zonula occludens type 1 •

Tight junction

\begin{abstract}
Tight junction molecules form a barrier between adjacent cells and mediate the cells' ability to develop membranes that constitute boundaries of different compartments within the body. Membranes with selective ion and water passage are important for the electrolyte and water homeostasis in the kidney. Due to their role in the urinary concentration process, renal medullary cells are exposed to hyperosmotic stress. Therefore, we were interested in the question of how mouse inner medullary collecting duct cells (mIMCD3) manage to maintain their cell-cell contacts, despite hypertonicity-induced cell shrinkage. Employing mRNA expression analysis, we found that the zonula occludens type 1 (Zo-1), multi-PDZ domain protein 1 (MUPP1) and cortactin mRNA levels were upregulated in a tonicitydependent manner. Using Western blot analysis, immunoprecipitation and immunofluorescence, we show that the Zo-1 protein is upregulated, phosphorylated and linked to the actin cytoskeleton in response to hypertonic stress. After cell exposure to hypertonicity, rearrangement of the actin cytoskeleton resulted in a stronger colocalization of actin fi-
\end{abstract}

\section{KARGER}

Fax +41613061234 E-Mail karger@karger.ch www.karger.com
(C) 2011 S. Karger AG, Basel

$1660-2137 / 11 / 1192-0011 \$ 38.00 / 0$

Accessible online at:

www.karger.com/nep bres with Zo-1. Urea, which generates hyperosmolality, but no transcellular gradient, did not induce changes in Zo-1 protein expression or actin rearrangement. This data indicates that Zo-1 is a response protein to inner medullary tonicity and that extracellular stressors can promote Zo-1 protein expression, tyrosine phosphorylation and cytoskeleton association.

Copyright $\odot 2011$ S. Karger AG, Basel

\section{Introduction}

A requirement for the development of multicellular organisms is the assembly of cell membranes that separate compartments of different ion, lipid and protein content and confer protection against the external environment. Under normal conditions, endothelia as well as epithelia guarantee these properties and the breakdown of such barriers may cause various diseases, e.g. pulmonary oedema, inflammatory bowel disease, nephropathies and tumors [1]. The ability of epithelial cell layers to separate the interstitial and the intraluminal space derives from

T.B. and C.T. contributed equally to this study.

Dr. med. Tobias Bergle

Klinik und Poliklinik für Innere Medizin II - Nephrologie, Universität Regensburg

Franz-Josef-Strauss-Allee 11

DE-93053 Regensburg (Germany)

Tel. +49941944 7301, E-Mail tobias.bergler@klinik.uni-regensburg.de 
intercellular adhesion mechanisms, which are composed of adherens junctions and tight junctions (TJ). Epithelial $\mathrm{TJ}$ are located near the apical cell surface and contain at least 40 different proteins [2]. They are composed of membrane-spanning proteins such as occludin and claudin, whose extracellular domains are connected to opposing TJ of the adjacent epithelial cells. Their intracellular domains bind to soluble $\mathrm{TJ}$ scaffolding proteins such as cingulin, multi-PDZ domain protein 1 (MUPP1), symplekin and zonula occludens (Zo) [3-7].

The Zo protein family consists of 3 different members, Zo-1, Zo-2 and Zo-3. These TJ scaffolding proteins belong to the MAGUK (membrane-associated guanylate kinase homolog) family, which is characterized by its PDZ domain, $\mathrm{SH} 3$ domain and guanylate kinase homologous domain [8]. The members of the Zo family differ primarily in the length of the $\mathrm{C}$ terminus, Zo-1 being the largest protein with $210-225 \mathrm{kDa}[2,9]$. Zo-1 was the first identified, characterized and is the most widely described TJ cytosolic accessory protein [10]. Zo proteins play a key role in the establishment and maintenance of TJ structure via their ability to form complexes with the apical T] proteins and actin [11-13]. Zo-1/2-deficient cultured epithelial cell lines exhibit no paracellular barrier function and Zo-1 is vital for embryonic development in mice [1416]. Furthermore, Zo-1 controls cell proliferation and migration as seen in various cancer cell lines and carcinomas, with decreased Zo-1 levels especially in metastases [17-19].

Together with occludin and claudin, Zo-1 forms a unique intercellular barrier between adjacent epithelial cells to control the passage of water, ions and macromolecules. This TJ barrier allows the selective exclusion of unnecessary or toxic molecules and the inclusion of useful and necessary components [20]. This is of special importance in the kidney, where the reabsorption of ions through paracellular pathways is crucial for the regulation of the electrolyte and water homeostasis [21]. To perform selective ion reabsorption or excretion, the nephron is composed of a series of functionally distinct segments, each having unique permeability characteristics [9]. The different fluid and solute transport capabilities are established by a varying distribution of TJ barrier components along the nephron: Zo-1 and occludin colocalize with a low expression in the 'leaky' proximal tubule, whereas increasing levels in more distal segments account for a more restrictive barrier phenotype [2, 22-24].

Due to their role in the urinary concentration mechanism, renal medullary cells are exposed to an extraordinary hyperosmotic stress [25]. During antidiuresis, when urine osmolality rises to $1,700 \mathrm{mosm} / \mathrm{kg}$, rat renal inner medullary cells are exposed to concentrations of $500 \mathrm{mM}$ $\mathrm{NaCl}$ and 1,000 $\mathrm{mM}$ urea or more [26]. To survive this hyperosmotic stress and to maintain their integrity as a cell sheet with barrier functions, these cells have to adapt. A great variety of proteins is upregulated and/or activated during hyperosmolality. Among them are kinases, small GTPases as well as cytoskeletal and TJ components [25, 27]. In the present study, we have addressed the question of how osmotic stress affects the TJ scaffolding protein Zo-1 in confluent mouse inner medullary collecting duct cell (mIMCD3) monolayers.

\section{Materials and Methods}

\section{Cell Culture Experiments}

Mouse Inner Medullary Collecting Duct Cells

The mIMCD3 cells (LGC Promochem, Wesel, Germany) were cultured in DMEM: $\mathrm{F}_{12}$ HAM (1:1) medium with L-glutamine (2.5 $\mathrm{mM})$, sodium pyruvate $(0.5 \mathrm{mM})$, HEPES $(15 \mathrm{mM})$ and sodium bicarbonate (1,200 mg/l; Sigma-Aldrich, Munich, Germany) containing 10\% heat-inactivated FCS-gold (PAA, Pasching, Austria) and a penicillin-streptomycin mixture $(50 \mathrm{IU} / \mathrm{ml})$ in a humidified atmosphere of $95 \%$ air and $5 \% \mathrm{CO}_{2}$ at $37^{\circ} \mathrm{C}$. Osmolality of the control medium was 300 mosm $/ \mathrm{kg} \mathrm{H}_{2} \mathrm{O}$.

Incubation of mIMCD3 Cells and RNA Isolation

mIMCD3 cells were incubated for $9 \mathrm{~h}$ with isosmotic medium (300 mosm $/ \mathrm{kg} \mathrm{H}_{2} \mathrm{O}$ ) or hyperosmotic medium (450-900 mosm/ $\mathrm{kg} \mathrm{H}{ }_{2} \mathrm{O}$ ) with addition of $\mathrm{NaCl}$. mIMCD3 cells were chronically adapted to hyperosmolality by a stepwise increase in osmolality every $12 \mathrm{~h}$ over $48 \mathrm{~h}$. To exclude any accompanying effects of hyperosmotic incubation on cell vitality that may affect the detected results, we performed an MTT [3-(4,5-dimethylthiazol-2-yl)-2,5diphenyltetrazolium bromide] cytovitality test (Sigma-Aldrich) under isosmotic and hyperosmotic (450-900 mosm/ $\mathrm{kg} \mathrm{H}_{2} \mathrm{O}$ ) incubation conditions. After iso-/hyperosmotic incubation, cells were incubated in a 96-well plate with $10 \mu \mathrm{l} \mathrm{MTT}$ for $4 \mathrm{~h}$ at $37^{\circ} \mathrm{C}$, $5 \% \mathrm{CO}_{2}$. SDS solution (20\%; Bio-Rad, Munich, Germany) was added for $2 \mathrm{~h}\left(37^{\circ} \mathrm{C}, 5 \% \mathrm{CO}_{2}\right)$ and optical density was measured. After incubation, total RNA was extracted using Qia Shredder columns (Qiagen, Hilden, Germany) and the RNeasy Mini Kit (Qiagen) according to the manufacturer's instructions with additional DNase digestion to remove all traces of genomic DNA.

Reverse Transcription and Real-Time PCR

Total RNA was reverse-transcribed into cDNA according to standard protocols as described previously [28], and real-time PCR was performed on an ABI Prism 7900 detection system (Applied Biosystems, Darmstadt, Germany) using the Quantitect SYBR Green PCR Kit (Qiagen) as described previously [28]. The data was analysed using the SDS 2.2.2 software (Applied Biosystems). The sequences of the used mouse primers are: Zo-1 (forward) 5'-actatgaccatcgcctacgg-3', Zo-1 (reverse) 5'-attctcaaaaggccgaggtt-3', MUPP1 (forward) 5' -tgtaccagctggagcttcct-3', MUPP1 (reverse) $5^{\prime}$-ccgtgctcagttaggctttc-3', cortactin (forward) $5^{\prime}$-gtgca- 
agctgaccgtgtaga-3', cortactin (reverse) 5'-aatcccatatttgccaccaa-3', cyclophilin (forward) $5^{\prime}$-tgatccagggtggagacttc- $3^{\prime}$, cyclophilin (reverse) $5^{\prime}$-attggtgtctttgcctgcat- $3^{\prime}$.

\section{Western Blot Analysis}

Confluently grown mIMCD3 cells were treated with isosmotic medium $\left(300 \mathrm{mosm} / \mathrm{kg} \mathrm{H}_{2} \mathrm{O}\right)$ or hyperosmotic medium (450 $\mathrm{mosm} / \mathrm{kg} \mathrm{H}_{2} \mathrm{O}$ ) for different time intervals (from 45 min to $48 \mathrm{~h}$ ). After the cells had been washed twice, $200 \mu \mathrm{l}$ of ice-cold RIPA buffer [150 mM NaCl, $50 \mathrm{~mm}$ Tris- $\mathrm{HCl}$ (pH 7.4), $0.5 \mathrm{~mm}$ phenylmethylsulphonyl fluoride, 2.4 mM EDTA, 1\% sodium desoxycholate, $1 \%$ Nonidet P40] with $4 \%$ protease inhibitor cocktail (SigmaAldrich) were added for $30 \mathrm{~min}$ on ice. Then the cells were scraped off the plate, incubated for $30 \mathrm{~min}$ on ice and repeatedly vortexed as described before [28]. Protein concentrations were determined in duplicate with the method of Pierce. A bicinchoninic acid and copper sulphate mixture (200 $\mu \mathrm{l} ; 50: 1$; Sigma-Aldrich) was combined with $10 \mu \mathrm{l}$ of the protein sample and incubated for $1 \mathrm{~h}$ at room temperature. Absorption was measured at $560 \mathrm{~nm}$. For Western blot analysis, equal amounts of protein $(30 \mu \mathrm{g})$ were boiled with Laemmli buffer (Bio-Rad) at $95^{\circ} \mathrm{C}$ for $5 \mathrm{~min}$, subjected to SDS-PAGE (10\%) and transferred to nitrocellulose membranes (Schleicher \& Schuell, Dassel, Germany) by semidry blotting. The membranes were washed, blocked for $90 \mathrm{~min}$ with Trisbuffered saline plus $0.1 \%$ Tween-20 containing $5 \%$ non-fat dry milk and incubated with the primary antibody (polyclonal rabbit anti-Zo-1, 1:2,000; Invitrogen, Karlsruhe, Germany) overnight at $4^{\circ} \mathrm{C}$. A horseradish-peroxidase-conjugated secondary antibody (Santa Cruz Biotechnology, Calif., USA) was used to detect immunoreactive bands using the enhanced chemiluminescence Western blotting detection system (Amersham Bioscience, UK). The membranes were exposed to Hyperfilm (Amersham-Bioscience).

Afterwards, the nitrocellulose membranes were stripped (30 min at $60^{\circ} \mathrm{C}$, stripping buffer: $100 \mathrm{mM}$ 2-mercaptoethanol, $2 \%$ SDS, $62.5 \mathrm{~mm}$ Tris-HCl, pH 7.6), washed and blocked with Trisbuffered saline plus $0.1 \%$ Tween-20 containing $5 \%$ non-fat dry milk for 90 min before the detection was performed with a goat anti- $\beta$-actin antibody (1:1,000; Santa Cruz Biotechnology; $1 \mathrm{~h}$ at room temperature) and a donkey anti-goat secondary antibody (1:2,000; Santa Cruz Biotechnology; $1 \mathrm{~h}$ at room temperature) coupled to peroxidase and enhanced chemiluminescence. For semiquantitative analysis, the signals were quantified using the Meta Morph 4.6.9r software from Universal Imaging (Visitron Systems, Puchheim, Germany).

\section{Extraction of the Triton-X-100-Soluble and-Insoluble Protein}

Fraction

Confluent mIMCD3 cells were treated with isosmotic or hyperosmotic medium as described above and subjected to a protein extraction protocol modified from that of Stamatovic et al. [29]. After incubation, the cells were rinsed with ice-cold PBS, layered with $1 \times$ ice-cold Triton X-100 extraction buffer [0.5\% Triton $\mathrm{X}-100,10 \mathrm{~mm}$ Tris-HCl (pH 7.4) $100 \mathrm{~mm} \mathrm{NaCl}, 300 \mathrm{~mm}$ sucrose] plus $4 \%$ protease inhibitor cocktail and incubated with gentle rocking for $20 \mathrm{~min}$ at $4^{\circ} \mathrm{C}$. The supernatant was transferred to a microtube and considered as the Triton-X-100-soluble protein fraction. The plate was subsequently incubated for $15 \mathrm{~min}$ on ice with the same volume of RIPA buffer plus $4 \%$ protease inhibitor cocktail, the cells were scraped off the plate, transferred to a mi- crotube, sonicated for $5 \mathrm{~s}$ and referred to as the Triton-X-100-insoluble protein fraction.

\section{Immunoprecipitation}

Confluent mIMCD3 cells were treated with isosmotic or hyperosmotic medium as described. After incubation, the cells were rinsed with ice-cold PBS and incubated with ice-cold cell lysis buffer [20 mM Tris- $\mathrm{HCl}$ ( $\mathrm{pH}$ 7.5), $150 \mathrm{~mm} \mathrm{NaCl}, 1 \mathrm{~mm}$ EDTA, $1 \mathrm{~mm}$ EGTA, 1\% Triton X-100, $2.5 \mathrm{~mm}$ sodium pyrophosphate, $1 \mathrm{mM} \beta$-glycerophosphate, $1 \mathrm{~mm} \mathrm{Na} \mathrm{VO}_{4}$ ] plus $4 \%$ protease inhibitor cocktail for $10 \mathrm{~min}$. The cells were scraped off the plate, transferred to a microtube and vortexed. After centrifugation (10 $\min$ at $4^{\circ} \mathrm{C}$ ), the supernatant was transferred to a fresh microtube. Immobilized phosphotyrosine mouse monoclonal antibody (20 $\mu \mathrm{l}$; Cell Signaling, Danvers, Mass., USA) was added to $500 \mu \mathrm{g}$ total protein. The samples were adjusted to the same total volume and incubated with gentle rocking overnight at $4^{\circ} \mathrm{C}$ followed by microcentrifugation for $30 \mathrm{~s}$ at $4^{\circ} \mathrm{C}$. The pellet was washed 5 times with $500 \mu \mathrm{l}$ ice-cold cell lysis buffer plus $4 \%$ protease inhibitor cocktail, resuspended with $20 \mu \mathrm{l}$ Laemmli buffer, vortexed, microcentrifuged for $30 \mathrm{~s}$ and boiled at $95^{\circ} \mathrm{C}$ for $5 \mathrm{~min}$. The sample was loaded on a $10 \%$ SDS-PAGE gel and analysed by Western blotting as described above.

\section{Fluorescence Microscopy}

For indirect immunofluorescence labelling, cultured mIMCD cells were confluently grown on collagen type-I-coated 2-well culture slides (BD Biosciences, Bedford, Mass., USA) and then treated with isosmotic medium $\left(300 \mathrm{mosm} / \mathrm{kg} \mathrm{H}_{2} \mathrm{O}\right)$ or hyperosmotic medium ( $450 \mathrm{mosm} / \mathrm{kg} \mathrm{H}_{2} \mathrm{O}$ ) for $24 \mathrm{~h}$. The cells were rinsed twice with PBS and fixed with $3.7 \%$ formaldehyde in PBS for 15 min at room temperature. After washing $(3 \times 2 \mathrm{~min}$ in PBS), the cells were permeabilized with $1 \%$ Triton $\mathrm{X}-100$ in PBS for $1 \mathrm{~min}$ and blocked for $30 \mathrm{~min}$ at room temperature with PBS containing 5\% non-fat dry milk. For detection of Zo-1, incubation with the primary antibody (rabbit anti-Zo-1, 1:150) was performed at $4^{\circ} \mathrm{C}$ overnight in PBS containing $1 \%$ non-fat dry milk. After washing, the cells were incubated with the secondary antibody (Alexa-546conjugated goat anti-rabbit antibody, 1:500; Santa Cruz Biotechnology; $1 \mathrm{~h}$ at room temperature).

F actin was detected with $50 \mu \mathrm{g} / \mathrm{ml}$ fluorescein isothiocyanate (FITC) phalloidin (Sigma, Deisenhofen, Germany). The nucleus staining was performed by incubation with trihydrochloride trihydrate (1:25,000 in PBS; Molecular Probes, Eugene, Oreg., USA) for $2 \mathrm{~min}$ at room temperature. The slides were washed with PBS and shielded with the antibleaching Fluorescent Mounting Medium (Dako-Cytoformation, Trappes, France). The fluorescence was examined using a $63 \times$ oil immersion objective and a Zeiss Axiovert 200 microscope (Zeiss, Jena, Germany). Representative images of each staining, which were done in duplicate, repeated independently and photographed with identical exposure times, are shown. The photographic images were resized, organized and labelled using the Photoshop software (Adobe, San Jose, Calif., USA).

\section{Statistical Analysis}

Results are presented as means \pm SE. Statistical significance between experimental groups was assessed by Student's t test or by analysis of variance followed by a t test. A value of $\mathrm{p}<0.05$ was considered as statistically significant. 


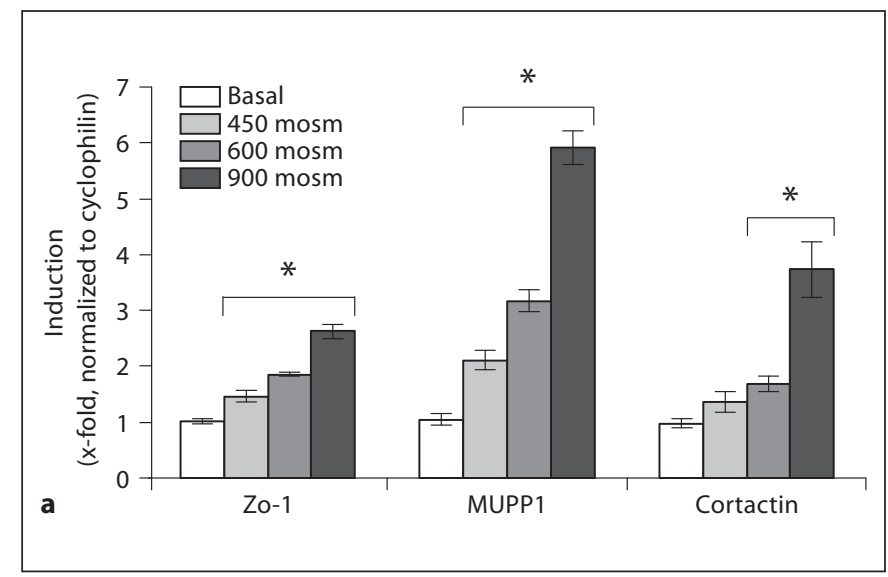

Fig. 1. Osmolality-dependent Zo-1 mRNA induction. a Concentration-dependent effect of hyperosmotic $\mathrm{NaCl}$ incubation (final osmolality $450-900$ mosm $/ \mathrm{kg} \mathrm{H}_{2} \mathrm{O}$ ) for $9 \mathrm{~h}$ on mRNA expression of target genes in confluent mIMCD3 cell monolayers. Pooled data $(n=4)$ are illustrated, and values are means \pm SE of target gene mRNA normalized to cyclophilin. ${ }^{*} \mathrm{p}<0.05$ versus control.

\section{Results}

\section{Effect of Osmolality on Zo-1 mRNA and Protein Expression}

Evaluating the impact of hyperosmolality on target gene expression of confluent mIMCD3 cell monolayers after $9 \mathrm{~h}$ of incubation by RT-PCR, we detected an osmolality-dependent influence. Zo-1 mRNA was upregulated 1.5-fold after incubation with $450 \mathrm{mosm} / \mathrm{kg} \mathrm{H}_{2} \mathrm{O}$ $\mathrm{NaCl}(\mathrm{p}=0.003)$, upregulated 1.8-fold with $600 \mathrm{mosm} /$ $\mathrm{kg} \mathrm{H}_{2} \mathrm{O} \mathrm{NaCl}\left(\mathrm{p}=5.9 \times 10^{-9}\right)$ and upregulated 2.6-fold using $900 \mathrm{mosm} / \mathrm{kg} \mathrm{H}_{2} \mathrm{O} \mathrm{NaCl}$ incubation $(\mathrm{p}=8.7 \times$ $10^{-7}$; fig. 1a). Not only Zo-1, but also MUPP1 and cortactin displayed an osmolality-driven mRNA upregulation. MUPP1 was upregulated 2-fold with $450 \mathrm{mosm} / \mathrm{kg}$ $\mathrm{H}_{2} \mathrm{O} \mathrm{NaCl}$ ( $\left.\mathrm{p}=0.0004\right)$, 3-fold with 600 mosm $/ \mathrm{kg} \mathrm{H}_{2} \mathrm{O}$ $\mathrm{NaCl}\left(\mathrm{p}=1.9 \times 10^{-6}\right)$ and 6-fold after incubation with $900 \mathrm{mosm} / \mathrm{kg} \mathrm{H}_{2} \mathrm{O} \mathrm{NaCl}\left(\mathrm{p}=1.4 \times 10^{-7}\right)$. Cortactin was only upregulated 1.4-fold after $9 \mathrm{~h}$ of $450 \mathrm{mosm} / \mathrm{kg} \mathrm{H}_{2} \mathrm{O}$ $\mathrm{NaCl}$ incubation ( $\mathrm{p}=0.07)$, but upregulated 1.7-fold with $600 \mathrm{mosm} / \mathrm{kg} \mathrm{H}_{2} \mathrm{O}(\mathrm{p}=0.001)$ and 3.7-fold after $900 \mathrm{mosm} / \mathrm{kg} \mathrm{H}_{2} \mathrm{O} \mathrm{NaCl}$ incubation ( $\left.\mathrm{p}=0.0004\right)$. Using the MTT assay, we ensured that hyperosmotic incubation had no accompanying effects on cell vitality that may affect the detected results (fig. 1b). Hyperosmotic co-incubation of $\mathrm{NaCl}$ with urea as well as raffinose with urea had no additional impact on osmolality-driven mRNA upregulation of Zo-1, MUPP1 or cortactin (data not shown). In contrast, after hyperosmotic co-

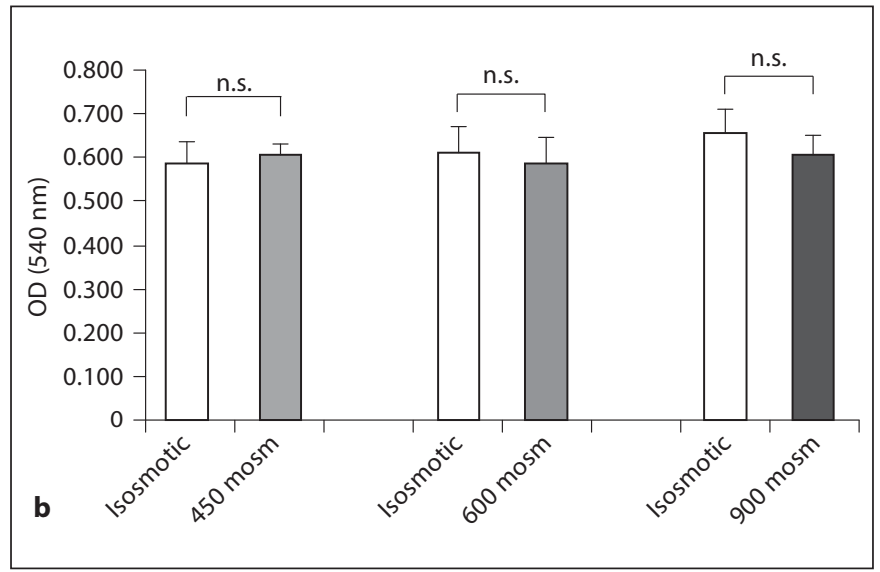

b Impact of hyperosmotic incubation for $9 \mathrm{~h}$ (final osmolality $450-900 \mathrm{mosm} / \mathrm{kg} \mathrm{H}_{2} \mathrm{O}$ ) on mIMCD3 cell vitality in comparison with isosmotic incubation $\left(300 \mathrm{mosm} / \mathrm{kg} \mathrm{H}_{2} \mathrm{O}\right)$ as detected by MTT assay. Pooled data $(n=12)$ are shown, and values are means \pm SE.

incubation of $\mathrm{NaCl}$ and raffinose, there was a trend for an additionally induced mRNA expression (data not shown).

Next, we examined the Zo-1 protein expression in confluently grown mIMCD3 cells subjected to hyperosmolality by Western blot analysis. Raising the osmolality to $450 \mathrm{mosm} / \mathrm{kg} \mathrm{H}_{2} \mathrm{O}$ by adding $\mathrm{NaCl}$ significantly increased the Zo-1 protein expression after an incubation time of only $6 \mathrm{~h}$ as compared with isosmotic conditions (fig. 2a, d). The Zo-1 protein induction peaked after $48 \mathrm{~h}$ of $\mathrm{NaCl}$ incubation. Incubation with raffinose $(450$ mosm $/ \mathrm{kg} \mathrm{H}_{2} \mathrm{O}$ ) also resulted in a significant increase in Zo-1 protein expression, which was similar in the intensity to mIMCD3 cells treated with $\mathrm{NaCl}$ (fig. 2b, d). In contrast, addition of surplus urea (final osmolality 450 mosm/ $\mathrm{kg} \mathrm{H}_{2} \mathrm{O}$ ) had no impact on the Zo-1 protein expression of confluently grown mIMCD cells (fig. 2c, d). Hyperosmotic treatment with $\mathrm{NaCl}$ as well as raffinose induced a variable second band. For semiquantitative analysis, the lower band was used.

\section{Influence of Osmolality on Zo-1 Immunofluorescence}

Immunochemical staining and fluorescence microscopy were conducted to assess the presence and localization of Zo-1 protein in mIMCD3 cells exposed to high extracellular osmolality. Confluently grown mIMCD3 cell monolayers treated with isosmotic medium displayed the typical polygonal cobblestone morphology. The Zo-1 immunofluorescence formed a continuous 


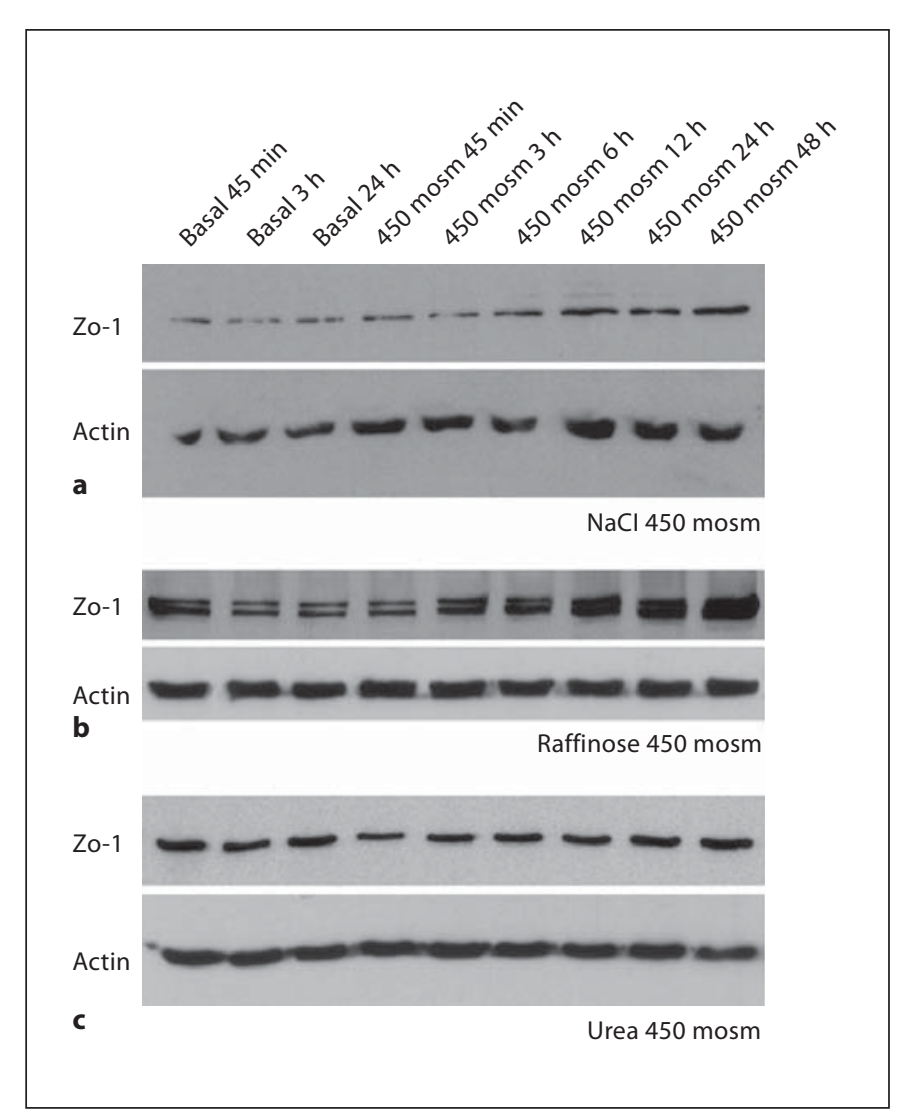

honeycomb-like staining (fig. 3a). In accordance with the increased Zo-1 protein expression (fig. 2), confluently grown mIMCD3 monolayers exposed to high osmolality for $24 \mathrm{~h}$ by addition of $\mathrm{NaCl}$ or raffinose also showed an intensified Zo-1 immunofluorescence (fig. 3b, c). Addition of surplus urea had no influence on Zo-1 immunofluorescence staining (data not shown). After addition of $\mathrm{NaCl}$, raffinose or urea, no changes were observed in the subcellular localization of the Zo-1 immunofluorescence.

\section{Influence of Osmolality on F Actin Fluorescence Staining}

To determine the effect of high extracellular osmolality on the subcellular $\mathrm{F}$ actin distribution of confluently grown mIMCD3 cell monolayers, $\mathrm{F}$ actin was visualized using FITC-labelled phalloidin. Under isosmotic conditions (300 mosm $/ \mathrm{kg} \mathrm{H}_{2} \mathrm{O}$ ), confluently grown mIMCD3 cell monolayers exhibited a distinct cortical $\mathrm{F}$ actin ring delineating the cell periphery (arrowhead, fig. 3a) as well as a network of cell-spanning F actin bundles (arrow, fig. 3a). After incubation with hyperosmotic medium for

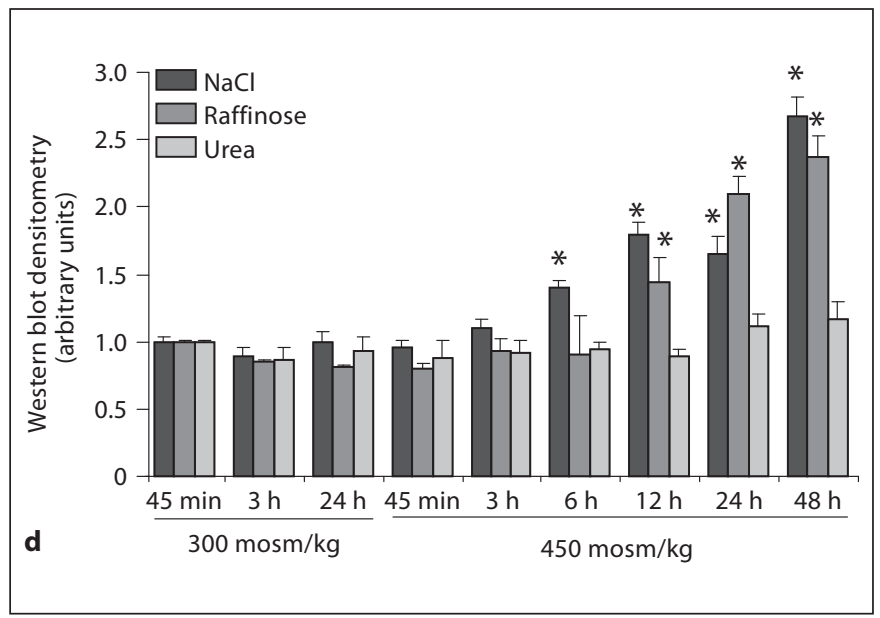

Fig. 2. Hyperosmolality increases Zo-1 protein expression. Confluently grown mIMCD3 cells were exposed to isosmotic medium (basal) or high $\mathrm{NaCl}(\mathbf{a})$, raffinose (b) or urea (c) in a final osmolality of $450 \mathrm{mosm} / \mathrm{kg} \mathrm{H}_{2} \mathrm{O}$ for different time intervals. Equivalent amounts of proteins $(30 \mu \mathrm{g})$ from total cell lysates were analysed by Western blot using an anti-Zo-1 antibody. $\beta$-Actin served as loading control. a Compared with basal values, exposure to high $\mathrm{NaCl}(\mathbf{a})$ and raffinose (b) induced an increased Zo-1 protein expression. c Addition of urea did not influence Zo-1 protein expression. d The signals from $3(\mathbf{a}, \mathbf{c})$ or 4 (b) independently repeated experiments were quantified using the Meta Morph 4.6.9r software; ${ }^{*} \mathrm{p}<0.05$ versus control.

$24 \mathrm{~h}$ by addition of $\mathrm{NaCl}$ (fig. 3b) or raffinose (fig. 3c; final osmolality 450 mosm $/ \mathrm{kg} \mathrm{H}_{2} \mathrm{O}$ ), the distribution pattern of $\mathrm{F}$ actin was disrupted. The high extracellular osmolality induced a rearrangement of the actin cytoskeleton with a preserved and more pronounced cortical $\mathrm{F}$ actin ring, which colocalized with the Zo-1 immunofluorescence. However, high extracellular osmolality due to $\mathrm{NaCl}$ or raffinose caused the dissolution of the central stress fibre meshwork, which displayed less developed actin bundles and a more diffuse phalloidin staining pattern.

\section{Influence of Osmolality on the Association of Zo-1 with the Actin Cytoskeleton}

The increased Zo-1 expression and altered actin cytoskeleton morphology in response to hyperosmotic stress reported above prompted us to investigate the distribution of Zo-1 protein in the Triton-X-100-soluble and -insoluble fractions as a marker for the interaction of Zo-1 with polymerized actin strands. Western blot analysis of control cells cultured under isosmotic conditions showed the Zo-1 protein to a smaller degree in the 
Zo-1
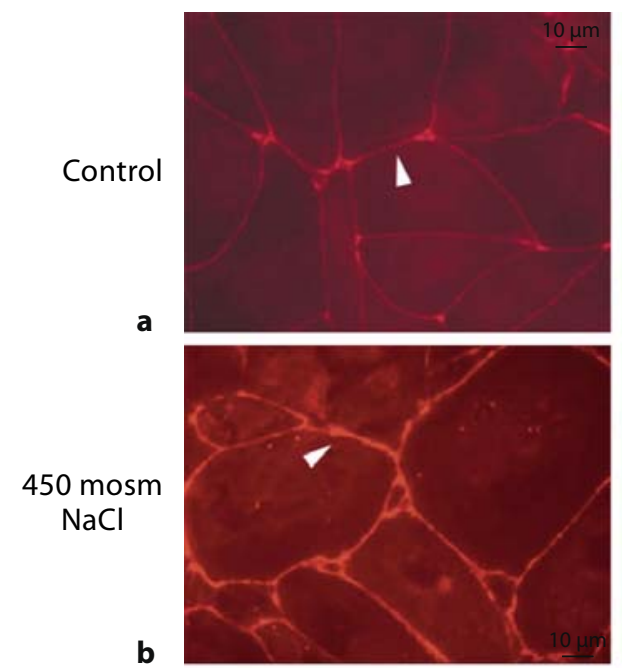

b
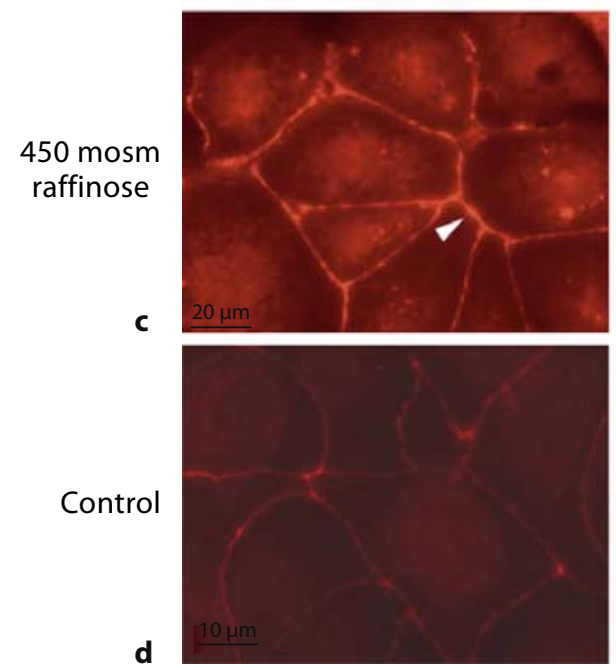

F actin
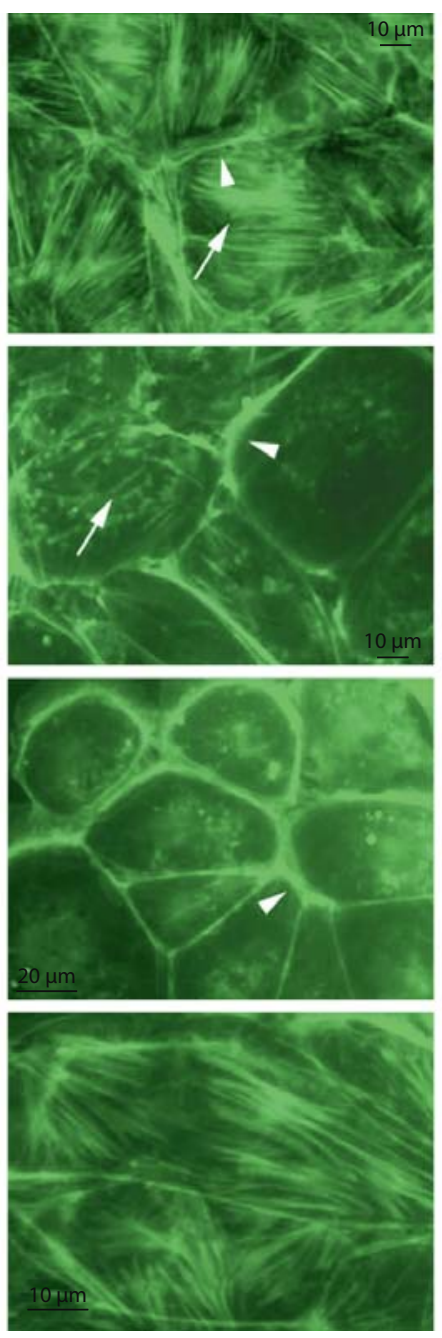

Merge/nuclei staining
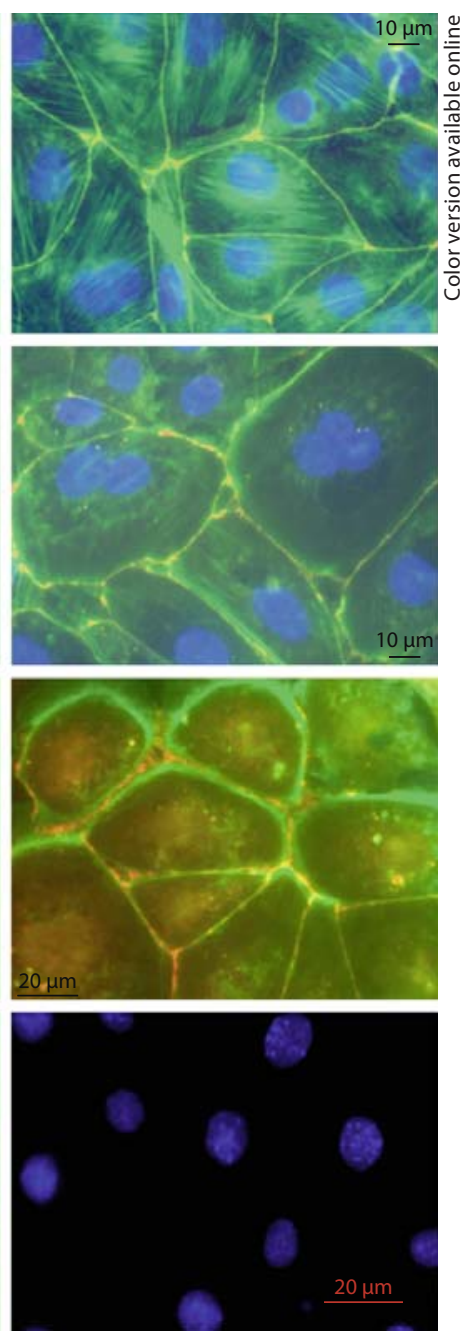

Fig. 3. Influence of hyperosmolality on Zo-1 immunofluorescence and $\mathrm{F}$ actin staining. mIMCD3 cells were confluently grown on collagen-covered glass slides, exposed to isosmotic medium for control (a) or $450 \mathrm{mosm} / \mathrm{kg} \mathrm{H}_{2} \mathrm{O} \mathrm{NaCl}$ (b) or raffinose (c) for $24 \mathrm{~h}$. Zo-1 immunofluorescence (red) was performed with a polyclonal rabbit anti-Zo-1 antibody; F actin was visualized by fluorescence microscopy after incubation with FITC-labelled phalloidin (green). a Cells treated with isosmotic medium showed the Zo-1 immunofluorescence encircling the cell borders (arrowhead) and a typical actin staining pattern with basal stress fibres (arrow) and a cortical actin ring (arrowhead). In contrast, cells treated with hyperosmolality by adding $\mathrm{NaCl}$ (b) or raffinose (c) showed an intensified Zo-1 immunofluorescence (arrowhead) and displayed a denser apical actin ring (arrowhead) and a less pronounced actin fibre network (arrow). Representative en face views of confluent mIMCD3 monolayers of 3 independently repeated experiments are shown. d Immunofluorescence controls of unstimulated confluent mIMCD3 cells stained with anti-Zo-1 antibody (left), phalloidin (middle) and trihydrochloride trihydrate (right) only.
Triton-X-100-insoluble, but mainly in the Triton-X-100soluble fraction. Incubation with hyperosmotic medium ( $450 \mathrm{mosm} / \mathrm{kg} \mathrm{H}_{2} \mathrm{O}$ ) by adding $\mathrm{NaCl}$ showed only a modest increase in the detergent-soluble Zo-1 protein fraction after $12 \mathrm{~h}$, which peaked after 24 and $30 \mathrm{~h}$ (fig. 4a). In contrast, the Triton X-100-insoluble Zo-1 fraction displayed a more rapid and substantial increase in expression levels, which were obvious $6 \mathrm{~h}$ after the onset of hyperosmotic stress (fig. 4b). The increased expression of the Triton X-100-insoluble Zo-1 fraction was stable for the following $24 \mathrm{~h}$. A similar rise of the Triton $\mathrm{X}$-100-soluble and -insoluble Zo-1 protein fractions was inducible by incubation with raffinose $(450 \mathrm{mosm} / \mathrm{kg}$ $\mathrm{H}_{2} \mathrm{O}$; fig. $4 \mathrm{a}, \mathrm{b}$ ). 


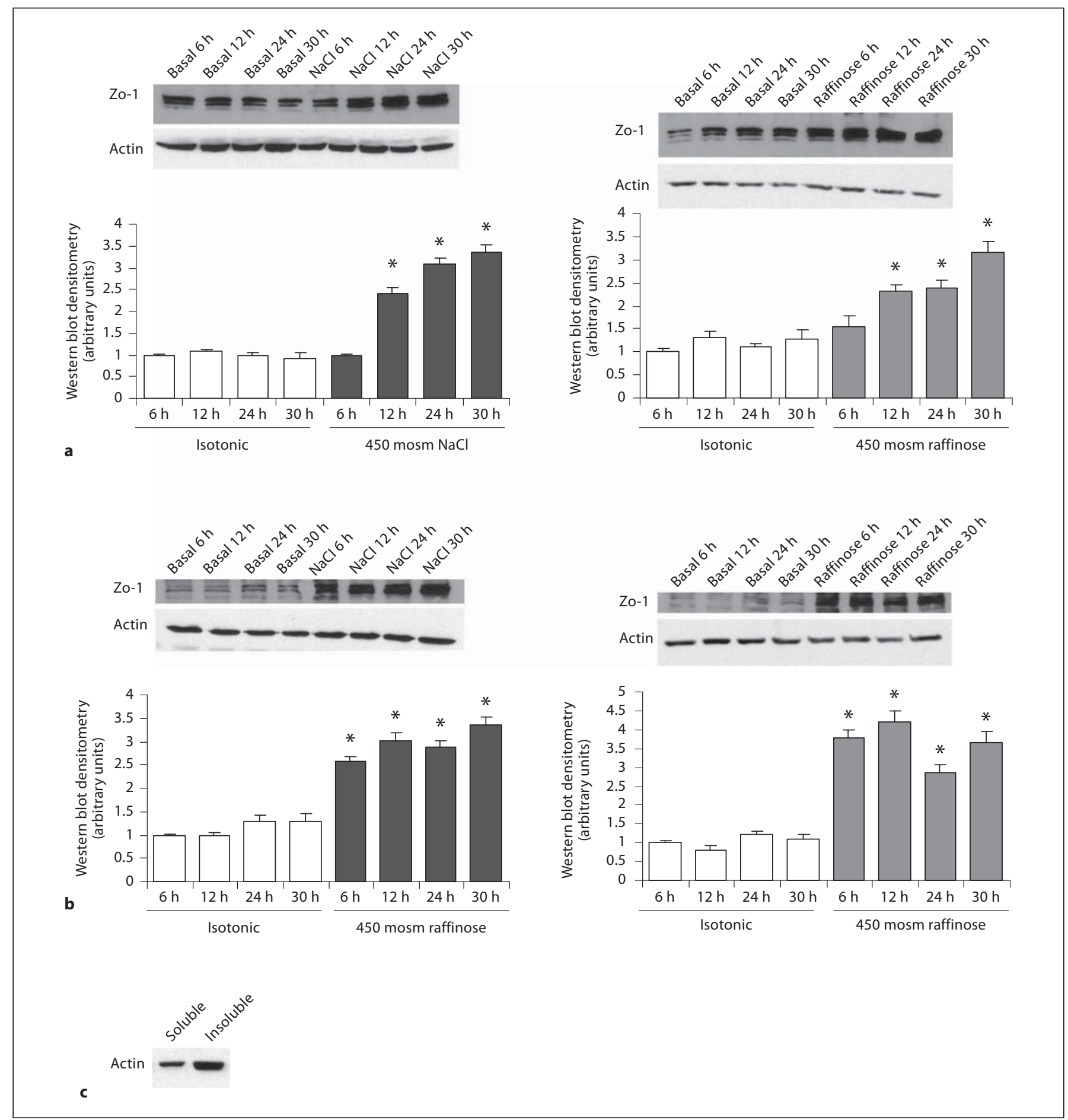

Fig. 4. Increase in the Zo-1 contents of Triton-X-100-soluble and -insoluble fractions. Confluent mIMCD3 cell monolayers were treated with isosmotic medium (basal) or 450 mosm $/ \mathrm{kg} \mathrm{H}_{2} \mathrm{O}$ $\mathrm{NaCl}$ or raffinose for the indicated time intervals. Equal amounts $(30 \mu \mathrm{g})$ of detergent-soluble and -insoluble protein fractions were immunoblotted. a Immunoblot analysis of Zo-1 in the Triton-X100 -soluble protein fraction of control cells (basal) and cells treated with $\mathrm{NaCl}$ or raffinose displayed a rise of $\mathrm{Zo}-1$ protein upon

hyperosmotic treatment. b Immunoblot analysis of the Triton-X100 -insoluble fraction showed a substantial Zo-1 protein increase in hyperosmolality-treated cells after $6 \mathrm{~h}$. The total actin content was stable in the detergent-soluble and -insoluble fractions after exposure to hypertonic stress. c Actin was mainly fractioned into the Triton-X-100-insoluble fraction. The semiquantitatively analysed data were collected from 3 independently repeated experiments. ${ }^{*} \mathrm{p}<0.05$ versus control. 


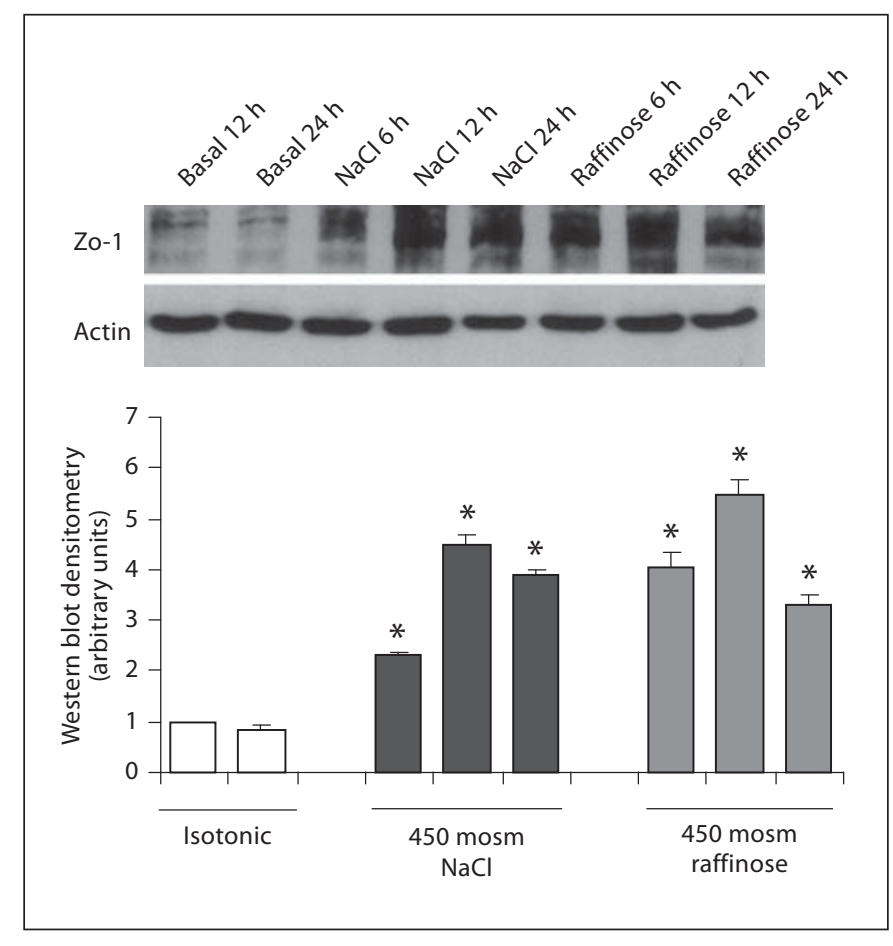

Fig. 5. Hyperosmolality promotes Zo-1 tyrosine phosphorylation. Confluently grown mIMCD3 cells were exposed to isosmotic (basal) or hyperosmotic $\left(\mathrm{NaCl}\right.$ or raffinose 450 mosm $/ \mathrm{kg} \mathrm{H}_{2} \mathrm{O}$ ) conditions for different time intervals. Equal amounts of protein $(500 \mu \mathrm{g})$ were subjected to immunoprecipitation with a monoclonal antiphosphotyrosine mouse antibody. Immune complexes were analysed by Western blot using an anti-Zo-1 antibody. $\beta$ Actin was used as loading control. Cells treated with isotonic medium expressed a modest amount of tyrosine-phosphorylated Zo-1 (basal). High $\mathrm{NaCl}$ or raffinose induced a significant increase in tyrosine phosphorylation of Zo-1 after $6 \mathrm{~h}$, which remained stable for the following $18 \mathrm{~h}$. Semiquantitatively analysed data was collected from 4 independently repeated experiments. ${ }^{*} \mathrm{p}<0.05$ versus control.

As determined by immunoblotting, the actin content was higher in the detergent-insoluble protein fraction as compared to the soluble fraction (fig. 4c). Hyperosmotic treatment with $\mathrm{NaCl}$ or raffinose did not alter the amount of Triton X-100-soluble or -insoluble actin as detected by Western blot analysis (fig. 4a, b).

\section{Impact of Osmolality on Zo-1 Tyrosine \\ Phosphorylation}

To evaluate the effect of extracellular hyperosmotic stress on Zo-1 phosphorylation on tyrosine residues, confluently grown mIMCD3 cells were treated with isosmotic medium or hyperosmotic medium (450 mosm $/ \mathrm{kg}$
$\mathrm{H}_{2} \mathrm{O} \mathrm{NaCl}$ or 450 mosm $/ \mathrm{kg} \mathrm{H}_{2} \mathrm{O}$ raffinose) for different time intervals $(6-24 \mathrm{~h})$. The isosmolality-treated control monolayers showed low levels of tyrosine-phosphorylated Zo-1 protein (fig. 5). Incubation of confluently grown mIMCD3 cells with $\mathrm{NaCl} 450 \mathrm{mosm} / \mathrm{kg} \mathrm{H}_{2} \mathrm{O}$ led to a significant increase in the Zo-1 tyrosine phosphorylation grade after an incubation time of only $6 \mathrm{~h}$ (fig. 5). The Zo-1 tyrosine phosphorylation level displayed a stable pattern for the ensuing $18 \mathrm{~h}$. A similar increase in Zo-1 tyrosine phosphorylation was achieved after treatment with raffinose 450 mosm $/ \mathrm{kg} \mathrm{H}_{2} \mathrm{O}$ (fig. 5).

\section{Discussion}

Under antidiuretic conditions, $\mathrm{NaCl}$ and urea are accumulated in the renal medulla, and subsequently, the inner medullary cells are exposed to varying osmolalities. Terrestrial organisms have the capacity to excrete highly concentrated urines that range from 1,200 mosm/ $\mathrm{kg} \mathrm{H}_{2} \mathrm{O}$ in humans up to 5,000 mosm $/ \mathrm{kg} \mathrm{H}_{2} \mathrm{O}$ in some desert rodents [30]. The mIMCD3 cell line provides a unique tool for studying the adaptive changes to osmotic stress in the collecting duct of the kidney. Extreme changes in inner medullary osmolality induce specific adaptation mechanisms in this type of tubular epithelial kidney cells. Modified expression of proteins, which are involved in organic osmolyte accumulation, ion transport, DNA repair and cell shrinkage, has been described [31-38]. However, little is known about how cells in coherent epithelial cell sheets maintain their cell-cell contacts despite osmotic cell stress. Since TJ proteins play a key role for the intercellular coherence of epithelial layers, the hypothesis to be tested in this study was if, how and in which time frame Zo-1, which links the apical TJ proteins to the cytoskeleton, is regulated by acute and chronic hyperosmotic stress in inner medullary collecting duct cells.

First, we examined, whether hyperosmolality had an impact on mRNA expression of TJ genes of confluent mIMCD3 monolayers. We detected an upregulation of Zo-1, MUPP1 and cortactin mRNA during hyperosmotic conditions induced by surplus $\mathrm{NaCl}$ (450-900 mosm/ $\mathrm{kg} \mathrm{H}_{2} \mathrm{O}$; fig. 1) and therefore verified previously published data on the upregulation of MUPP1 [27, 31]. Coincubation of $\mathrm{NaCl}$ and urea, a solute that due to its high membrane permeability does not set up a cellular osmotic gradient, resulted in a lower Zo-1 expression level, which, however, did not achieve statistical significance. These data are in line with publications, which stated that the effects of $\mathrm{NaCl}$ and urea are not synergistic [39] but 
may counteract the influence of each other [40]. However, a clear protective effect of urea against cell shrinkage possibly resulting in a decreased Zo-1 induction could not be demonstrated.

Under isosmotic conditions, confluent mIMCD3 cells were found to express substantial, but low levels of Zo-1 protein. However, Zo-1 protein expression increased rapidly upon acute exposure of the cells to osmotic stress after an incubation time of only $6 \mathrm{~h}$, a time frame similar to that of early-response proteins, e.g. AR and SMIT, which are induced during cell volume recovery after high osmotic stress [41]. The upregulation persisted for the observed time interval of $48 \mathrm{~h}$, indicating an early beginning but also long-lasting adaptation mechanism.

However, it is known that $\mathrm{NaCl}$ does not only raise the osmolality, but might also have specific effects on the incubated cells by itself, such as the upregulation of the $\gamma$ subunit of the $\mathrm{Na} / \mathrm{K}$-ATPase $[30,42]$. Specific effects on the regulation of $\mathrm{TJ}$ proteins have not been described yet. To rule out that the increased Zo-1 expression is a specific effect of $\mathrm{NaCl}$, the poorly permeating trisaccharide raffinose was used to reproduce high tonicity. Exposure to raffinose (final osmolality $450 \mathrm{mosm} / \mathrm{kg} \mathrm{H}_{2} \mathrm{O}$ ) resulted in a similar $\mathrm{Zo}-1$ protein expression, demonstrating that the increase in Zo-1 protein expression is caused by hyperosmolality per se and not by a specific $\mathrm{NaCl}$-induced effect. In contrast, urea did not affect the Zo-1 protein expression of confluent mIMCD3 cell monolayers.

Immunocytochemical examination of Zo-1 in confluent mIMCD3 monolayers treated with high $\mathrm{NaCl}$ or raffinose confirmed the increased Zo-1 protein expression by displaying an intensified honeycomb-like Zo-1 immunofluorescence.

The examination of the $\mathrm{F}$ actin fluorescence with FITC-labelled phalloidin revealed a hyperosmolality-induced rearrangement of the actin cytoskeleton with a denser cortical actin ring, which colocalized with the Zo-1 immunofluorescence. The cytoskeleton plays a well-known role in the cellular response to osmotic environmental changes, as regards both hypo- and hypertonicity, and changes in the arrangement of the cytoskeleton in different cell lines have been described previously $[25,37,38,43-46]$. The denser perijunctional $\mathrm{F}$ actin ring and its colocalization with Zo-1 prompted us to examine the interaction of Zo-1 and the actin cytoskeleton in cells forming a confluent monolayer under isosmotic and hyperosmotic conditions. Zo-1 can bind directly to actin filaments [47], linking apical TJ molecules to the cytoskeleton. In the hyperosmolality-treated confluent mIMCD3 cell monolayers, we observed an increase in the
F-actin-bound Zo-1 protein fraction as compared to the control cells, regardless of whether the hypertonicity was due to $\mathrm{NaCl}$ or to raffinose. The faster increase in the Triton-X-100-insoluble Zo-1 fraction was probably mainly due to an increased anchorage of Zo-1 to the actin cytoskeleton. In this process, in parallel to the upregulation of the overall Zo-1 protein content in the cell, Zo-1 might be initially taken out of a pool of soluble Zo-1 proteins already existing in the cell with little time delay. A saturation of binding sites is also possible, preventing a further increase in the Triton-X-100-insoluble Zo-1 fraction. In contrast, the increase of Zo-1 in the Triton-X-100-soluble fraction might be mainly caused by an elevated Zo-1 expression by de novo synthesis, which takes more time.

Thus, we assume that the intensified cortical $\mathrm{F}$ actin staining might be related to an increased anchorage of actin filaments to scaffolding proteins near the plasma membrane, probably due to the increased amount of Zo-1 expressed and linked to the cytoskeleton.

The exact role of the cytoskeleton in osmoregulation remains speculative. As in other dynamic cell processes such as cell migration and phagocytosis, the $\mathrm{F}$ actin assembly is induced by the combined action of kinases, small GTPases and actin-binding proteins, for example Arp2/3 and cortactin $[46,47]$. Numerous actin-regulating proteins, including Src kinases, phosphatases, small GTPases and the phosphatidylinositol 3-kinase have been shown to be associated with the TJ complex and to play a role for TJ regulation $[25,48,49]$, and Zo-1 directly interacts with cortactin in polarized and migrating colorectal cancer cells. Being integrated in a complex array of membrane spanning and cytoskeletal proteins involved in signalling cascades, the TJ scaffolding proteins might constitute an important link between the extracellular and the intracellular space. In demonstrating an upregulation of cortactin mRNA in parallel with Zo-1 mRNA in response to hyperosmolality, our data support this hypothesis.

$\mathrm{TJ}$ in confluent cell monolayers are among the first cell structures to be affected by hypertonicity-induced cell shrinkage, since they are exposed to intercellular traction forces when the adjacent cell membranes retreat from each other. Together with the numerous signal transduction molecules identified in the TJ complex, the TJ scaffolding proteins might initiate signalling cascades leading to actin-mediated mechanical protection against the deleterious effects of excessive shrinkage as well as their own assembly and disassembly. Fast Zo-1 regulation might therefore be essential for an adequate response to high tonicity in confluent cell monolayers in order to 
maintain cell-cell contacts. Especially phosphorylation seems to be an important factor in the manipulation of Zo-1 and other TJ proteins in a so far controversially discussed manner. Phosphorylation of TJ proteins might sustain TJ integrity as the reassembly of TJ after oxidative stress depends on tyrosine kinase activity [50]. Zo-1 tyrosine phosphorylation is associated with Zo-1 redistribution from the lateral membrane to the apical cell borders in A431 cells [51] and with the formation of TJ in glomeruli [52], suggesting that tyrosine phosphorylation of Zo-1 is involved in targeting these proteins into the TJ. On the other hand, Src-mediated tyrosine phosphorylation of occludin prevents its interaction with Zo-1 [53] and enhances the permeability of the blood-brain barrier after a transient focal cerebral ischaemia [54], and Zo-1 tyrosine phosphorylation is correlated with enhanced vascular permeability and decreased transepithelial resistance of Madin-Darby canine kidney cell layers $[1,55]$. Thus, Zo-1 tyrosine phosphorylation plays an important role in enhanced permeability and junctional remodelling and is involved in the regulation of both the disassembly and the reassembly of TJ. In the present study, we show that hyperosmotic stress caused by $\mathrm{NaCl}$ or raffinose promotes Zo-1 tyrosine phosphorylation, which, in this setting, may be part of an outside-in-signalling pathway during high extracellular tonicity. In conclusion, our experiments indicate that the TJ scaffolding protein $\mathrm{Zo}-1$ is a response protein to hyperosmolality in confluent mIMCD3 cell layers and that extracellular stressors can promote Zo-1 mRNA and protein expression, tyrosine phosphorylation and $\mathrm{F}$ actin association.

\section{Acknowledgements}

We thank Mrs. Stefanie Ellmann and Mrs. Alexandra Wilhelm for their excellent technical assistance. This work was supported by the Regensburger Forschungsförderung in der Medizin (ReForM A-project) to T.B.

\section{Disclosure Statement}

The authors have no conflict of interest/competing interests with regard to the present study.

\section{References}

1 Harhaj NS, Antonetti DA: Regulation of tight junctions and loss of barrier function in pathophysiology. Int J Biochem Cell Biol 2004;36:1206-1237.

-2 Gonzalez-Mariscal L, Betanzos A, Nava P, Jaramillo BE: Tight junction proteins. Prog Biophys Mol Biol 2003;81:1-44.

- 3 Furuse M, Itoh M, Hirase T, Nagafuchi A, Yonemura S, Tsukita S, Tsukita S: Direct association of occludin with ZO-1 and its possible involvement in the localization of occludin at tight junctions. J Cell Biol 1994;127: 1617-1626.

-4 Li Y, Fanning AS, Anderson JM, Lavie A: Structure of the conserved cytoplasmic Cterminal domain of occludin: identification of the ZO-1 binding surface. J Mol Biol 2005; 352:151-164.

5 Itoh M, Furuse M, Morita K, Kubota K, Saitou M, Tsukita S: Direct binding of three tight junction-associated MAGUKs, ZO-1, $\mathrm{ZO}-2$, and $\mathrm{ZO}-3$, with the $\mathrm{COOH}$ termini of claudins. J Cell Biol 1999;147:1351-1363.

-6 Citi S, Cordenonsi M: Tight junction proteins. Biochim Biophys Acta 1998;1448:1-11.

7 Miyoshi J, Takai Y: Molecular perspective on tight-junction assembly and epithelial polarity. Adv Drug Deliv Rev 2005;57:815-855.

-8 Funke L, Dakoji S, Bredt DS: Membrane-associated guanylate kinases regulate adhesion and plasticity at cell junctions. Annu Rev Biochem 2005;74:219-245.
\$9 Prozialeck WC, Edwards JR, Lamar PC Evaluation of the barrier properties of a commercially available renal epithelial cell system. Toxicol In Vitro 2007;21:533.

10 Stevenson BR, Siliciano JD, Mooseker MS, Goodenough DA: Identification of ZO-1: a high molecular weight polypeptide associated with the tight junction (zonula occludens) in a variety of epithelia. J Cell Biol 1986;103:755-766.

11 Van Itallie CM, Fanning AS, Bridges A, Anderson JM: ZO-1 stabilizes the tight junction solute barrier through coupling to the perijunctional cytoskeleton. Mol Biol Cell 2009; 20:3930-3940.

12 Fanning AS, Anderson JM: Zonula occludens- 1 and -2 are cytosolic scaffolds that regulate the assembly of cellular junctions. Ann NY Acad Sci 2009;1165:113-120.

13 Tsukita S, Katsuno T, Yamazaki Y, Umeda K, Tamura A, Tsukita S: Roles of ZO-1 and ZO-2 in establishment of the belt-like adherens and tight junctions with paracellular permselective barrier function. Ann NY Acad Sci 2009;1165:44-52.

14 Umeda K, Ikenouchi J, Katahira-Tayama S, Furuse K, Sasaki H, Nakayama M, Matsui T, Tsukita S, Furuse M, Tsukita S: ZO-1 and $\mathrm{ZO}-2$ independently determine where claudins are polymerized in tight-junction strand formation. Cell 2006;126:741-754.
15 Katsuno T, Umeda K, Matsui T, Hata M, Tamura A, Itoh M, Takeuchi K, Fujimori T, Nabeshima Y, Noda T, Tsukita S, Tsukita S: Deficiency of zonula occludens-1 causes embryonic lethal phenotype associated with defected yolk sac angiogenesis and apoptosis of embryonic cells. Mol Biol Cell 2008; 19 : 2465-2475

16 Xu J, Kausalya PJ, Phua DC, Ali SM, Hossain Z, Hunziker W: Early embryonic lethality of mice lacking ZO-2, but Not ZO-3, reveals critical and nonredundant roles for individual zonula occludens proteins in mammalian development. Mol Cell Biol 2008;28: 1669-1678.

17 Orban E, Szabo E, Lotz G, Kupcsulik P, Paska C, Schaff Z, Kiss A: Different expression of occludin and ZO-1 in primary and metastatic liver tumors. Pathol Oncol Res 2008; 14:299-306.

18 Nemeth Z, Szasz AM, Somoracz A, Tatrai P, Nemeth J, Gyorffy H, Szijarto A, Kupcsulik P, Kiss A, Schaff Z: Zonula occludens-1, occludin, and E-cadherin protein expression in biliary tract cancers. Pathol Oncol Res 2009; 15:533-539.

19 Erin N, Wang N, Xin P, Bui V, Weisz J, Barkan GA, Zhao W, Shearer D, Clawson GA: Altered gene expression in breast cancer liver metastases. Int J Cancer 2009;124:15031516. 
20 Hartsock A, Nelson WJ: Adherens and tight junctions: structure, function and connections to the actin cytoskeleton. Biochim Biophys Acta 2008;1778:660-669.

-21 Simon DB, Lu Y, Choate KA, Velazquez H, Al-Sabban E, Praga M, Casari G, Bettinelli A, Colussi G, Rodriguez-Soriano J, McCredie D, Milford D, Sanjad S, Lifton RP: Paracellin-1, a renal tight junction protein required for paracellular $\mathrm{Mg}^{2+}$ resorption. Science 1999;285:103-106.

-22 Kiuchi-Saishin Y, Gotoh S, Furuse M, Takasuga A, Tano Y, Tsukita S: Differential expression patterns of claudins, tight junction membrane proteins, in mouse nephron segments. J Am Soc Nephrol 2002;13:875-886.

-23 Raschperger E, Thyberg J, Pettersson S, Philipson L, Fuxe J, Pettersson RF: The coxsackie- and adenovirus receptor (CAR) is an in vivo marker for epithelial tight junctions, with a potential role in regulating permeability and tissue homeostasis. Exp Cell Res 2006;312:1566-1580.

-24 Reyes JL, Lamas M, Martin D, del Carmen NM, Islas S, Luna J, Tauc M, Gonzalez-Mariscal L: The renal segmental distribution of claudins changes with development. Kidney Int 2002;62:476-487.

-25 Burg MB, Ferraris JD, Dmitrieva NI: Cellular response to hyperosmotic stresses. Physiol Rev 2007;87:1441-1474.

26 Burg MB: Response of renal inner medullary epithelial cells to osmotic stress. Comp Biochem Physiol A Mol Integr Physiol 2002;133: 661-666.

-27 Lanaspa MA, Almeida NE, Andres-Hernando A, Rivard CJ, Capasso JM, Berl T: The tight junction protein, MUPP1, is up-regulated by hypertonicity and is important in the osmotic stress response in kidney cells. Proc Natl Acad Sci USA 2007;104:1367213677.

-28 Bergler T, Stoelcker B, Jeblick R, Reinhold SW, Wolf K, Riegger GA, Kramer BK: High osmolality induces the kidney-specific chloride channel CLC-K1 by a serum and glucocorticoid-inducible kinase 1 MAPK pathway. Kidney Int 2008;74:1170-1177.

-29 Stamatovic SM, Keep RF, Kunkel SL, Andjelkovic AV: Potential role of MCP-1 in endothelial cell tight junction 'opening': signaling via Rho and Rho kinase. J Cell Sci 2003;116: 4615-4628.

30 Berl T: How do kidney cells adapt to survive in hypertonic inner medulla? Trans Am Clin Climatol Assoc 2009;120:389-401.

>31 Uawithya P, Pisitkun T, Ruttenberg BE, Knepper MA: Transcriptional profiling of native inner medullary collecting duct cells from rat kidney. Physiol Genomics 2008;32: 229-253.

>32 Burg MB, Kwon ED, Kultz D: Regulation of gene expression by hypertonicity. Annu Rev Physiol 1997;59:437-455.
33 Ferraris JD, Burg MB: Tonicity-dependent regulation of osmoprotective genes in mammalian cells. Contrib Nephrol 2006;152 125-141.

34 Dmitrieva NI, Burg MB, Ferraris JD: DNA damage and osmotic regulation in the kidney. Am J Physiol Renal Physiol 2005;289. F2-F7.

35 Handler JS, Kwon HM: Cell and molecular biology of organic osmolyte accumulation in hypertonic renal cells. Nephron 2001;87: 106-110.

36 Sheen MR, Kim SW, Jung JY, Ahn JY, Rhee JG, Kwon HM, Woo SK: Mre11-Rad50-Nbs1 complex is activated by hypertonicity. Am J Physiol Renal Physiol 2006;291:F1014F1020.

37 Thirone AC, Speight P, Zulys M, Rotstein OD, Szaszi K, Pedersen SF, Kapus A: Hyperosmotic stress induces Rho/Rho kinase/LIM kinase-mediated cofilin phosphorylation in tubular cells: key role in the osmotically triggered F-actin response. Am J Physiol Cell Physiol 2009;296:C463-C475.

38 Correa LM, Thomas A, Meyers SA: The macaque sperm actin cytoskeleton reorganizes in response to osmotic stress and contributes to morphological defects and decreased motility. Biol Reprod 2007;77:942-953.

39 Michea L, Combs C, Andrews P, Dmitrieva N, Burg MB: Mitochondrial dysfunction is an early event in high-NaCl-induced apoptosis of mIMCD3 cells. Am J Physiol Renal Physiol 2002;282:F981-F990.

-40 Neuhofer W, Muller E, Burger-Kentischer A, Fraek ML, Thurau K, Beck F: Pretreatment with hypertonic $\mathrm{NaCl}$ protects MDCK cells against high urea concentrations. Pflugers Arch 1998;435:407-414.

41 Neuhofer W, Steinert D, Fraek ML, Beck FX: Prostaglandin $\mathrm{E}_{2}$ stimulates expression of osmoprotective genes in MDCK cells and promotes survival under hypertonic conditions. J Physiol 2007;583:287-297.

42 Capasso JM, Rivard CJ, Enomoto LM, Berl T: Chloride, not sodium, stimulates expression of the gamma subunit of $\mathrm{Na} / \mathrm{K}$-ATPase and activates JNK in response to hypertonicity in mouse IMCD3 cells. Proc Natl Acad Sci USA 2003;100:6428-6433.

43 Bustamante M, Roger F, Bochaton-Piallat ML, Gabbiani G, Martin PY, Feraille E: Regulatory volume increase is associated with p38 kinase-dependent actin cytoskeleton remodeling in rat kidney MTAL. Am J Physiol Renal Physiol 2003;285:F336-F347.

44 Pedersen SF, Hoffmann EK, Mills JW: The cytoskeleton and cell volume regulation. Comp Biochem Physiol A Mol Integr Physiol 2001;130:385-399.

45 Fanning AS, Jameson BJ, Jesaitis LA, Anderson JM: The tight junction protein $\mathrm{ZO}-1$ establishes a link between the transmembrane protein occludin and the actin cytoskeleton. J Biol Chem 1998;273:29745-29753.
46 Di CC, Nie Z, Szaszi K, Lewis A, Uruno T, Zhan X, Rotstein OD, Mak A, Kapus A: Osmotic stress-induced remodeling of the cortical cytoskeleton. Am J Physiol Cell Physiol 2002;283:C850-C865.

47 Rasmussen M, Alexander RT, Darborg BV, Mobjerg N, Hoffmann EK, Kapus A, Pedersen SF: Osmotic cell shrinkage activates ezrin/radixin/moesin (ERM) proteins: activation mechanisms and physiological implications. Am J Physiol Cell Physiol 2008; 294:C197-C212.

48 Gilleron J, Fiorini C, Carette D, Avondet C, Falk MM, Segretain D, Pointis G: Molecular reorganization of $\mathrm{Cx} 43, \mathrm{Zo}-1$ and Src complexes during the endocytosis of gap junction plaques in response to a non-genomic carcinogen. J Cell Sci 2008;121:4069-4078.

49 Saito K, Enya K, Oneyama C, Hikita T, Okada $\mathrm{M}$ : Proteomic identification of $\mathrm{ZO}-1 / 2$ as a novel scaffold for Src/Csk regulatory circuit. Biochem Biophys Res Commun 2008; 366:969-975.

-50 Meyer TN, Schwesinger C, Ye J, Denker BM, Nigam SK: Reassembly of the tight junction after oxidative stress depends on tyrosine kinase activity. J Biol Chem 2001;276:2204822055.

51 Van Itallie CM, Balda MS, Anderson JM: Epidermal growth factor induces tyrosine phosphorylation and reorganization of the tight junction protein ZO-1 in A431 cells. J Cell Sci 1995;108:1735-1742.

-52 Kurihara H, Anderson JM, Farquhar MG: Increased Tyr phosphorylation of ZO-1 during modification of tight junctions between glomerular foot processes. Am J Physiol 1995;268:F514-F524.

53 Elias BC, Suzuki T, Seth A, Giorgianni F, Kale G, Shen L, Turner JR, Naren A, Desiderio DM, Rao R: Phosphorylation of Tyr-398 and Tyr-402 in occludin prevents its interaction with ZO-1 and destabilizes its assembly at the tight junctions. J Biol Chem 2009;284: 1559-1569.

54 Takenaga Y, Takagi N, Murotomi K, Tanonaka K, Takeo S: Inhibition of Src activity decreases tyrosine phosphorylation of occludin in brain capillaries and attenuates increase in permeability of the blood-brain barrier after transient focal cerebral ischemia. J Cereb Blood Flow Metab 2009;29: 1099-1108.

55 Antonetti DA, Barber AJ, Hollinger LA, Wolpert EB, Gardner TW: Vascular endothelial growth factor induces rapid phosphorylation of tight junction proteins occludin and zonula occludens 1: a potential mechanism for vascular permeability in diabetic retinopathy and tumors. J Biol Chem 1999;274:23463-23467. 